$p$-ISSN 1693-9484, $e$-ISSN : 2621-8313

Majalah Ilmiah Bahari Jogja (MIBJ)

Vol. 17 No. 1, Februari 2019 (63-70)

DOI : $10.33489 /$ mibj.v17i1.186

(C) 2019 Akademi Maritim Yogyakarta

\title{
Pengaruh Pendekatan Realistic Mathematics Education \\ Bidang Teknika Pelayaran Dalam Meningkatkan Minat Belajar Taruna
}

\author{
Ningrum Astriawati ${ }^{1 *}$, Yudhi Setiyantara ${ }^{2}$ \\ ${ }^{1}$ Jurusan Teknika, Akademi Maritim Yogyakarta, Jl. Magelang KM 4.4, Yogyakarta \\ 55284, Indonesia \\ ${ }^{2}$ Jurusan Nautika, Akademi Maritim Yogyakarta, Jl. Magelang KM 4.4, Yogyakarta \\ 55284, Indonesia \\ *Corresponding Author. E-mail : astriamath@gmail.com. Telp : +628995769219
}

\begin{abstract}
Abstrak
Penelitian ini bertujuan untuk menguji pengaruh pendekatan Realistic Mathematics Education bidang teknika pelayaran terhadap minat belajar taruna. Penelitian ini dilaksanakan di Jurusan Teknika, Akademi Maritim Yogyakarta. Subjek penelitian ini adalah Taruna semester I Tahun Akademik 2018/2019 dengan jumlah peserta didik sebanyak 43 orang yang mengambil mata kuliah Matematika Terapan. Jenis penelitian merupakan penelitian true experiment design dengan melibatkan satu kelas eksperimen dan satu kelas kontrol, desain pre-testpost-test control group design. Instrumen penelitian yang digunakan dalam penelitian ini terdiri atas instrumen lembar observasi dan instrumen kuesioner. Data di analisis secara deskriptif. Hasil analisis data menunjukkan bahwa pelaksanaan pendekatan Realistic Mathematics Education sangat berpengaruh untuk meningkatkan minat belajar taruna. Selain itu taruna memiliki respon yang sangat positif terhadap pembelajaran Matematika Terapan dengan menggunakan pendekatan Realistic Mathematics Education.
\end{abstract}

Kata Kunci: Realistic Mathematics Education, Minat Belajar

\begin{abstract}
This study aims to examine the effect of the Realistic Mathematics Education On Shipping Engineering approach in cadets' learning interest. This research was conducted at the Engineering Department of Yogyakarta Maritime Academy. The subjects of this study were 43 cadets of first semester in Academic Year of 2018/2019 with the taking the Applied Mathematics course. This type of research is a true experiment design involving one experimental class and one control class, the design of pre-test-post-test control group design. The research instrument used in this study consisted of observation sheet and questionnaire. Data was analyzed descriptively. The results of data analysis show that the implementation of the Realistic Mathematics Education approach is very influential to increase the interest in cadets' learning. Besides that cadets have a very positive response to the learning of Applied Mathematics using the Realistic Mathematics Education approach.
\end{abstract}

Keywords: Realistic Mathematics Education, Learning Interest 


\section{PENDAHULUAN}

Minat belajar peserta didik dalam mengikuti pembelajaran merupakan sesuatu yang penting dalam kelancaran proses belajar mengajar. Peserta didik yang mempunyai minat belajar tinggi dalam proses pembelajaran dapat menunjang proses belajar mengajar semakin baik, begitupun sebaliknya minat belajar peserta didik yang rendah maka kualitas pembelajaran akan menurun dan akan berpengaruh pada hasil belajar. Minat adalah "Kecenderungan hati yang tinggi terhadap sesuatu" (Slameto, 1995). Minat merupakan sifat yang relatif menetap pada diri seseorang. Minat adalah ketertarikan atau kecenderungan yang tetap untuk memperhatikan atau terlibat terhadap sesuatu hal karena menyadari pentingnya atau bernilainya hal tersebut.

Apabila minat belajar peserta didik rendah dapat menyebabkan kesulitan belajar. Kesulitan peserta didik dalam memahami materi merupakan salah satu penghambat dalam proses belajar mengajar (Prahmana, Zulkardi, \& Hartono, 2012). Salah satu penyebab dari hal tersebut ialah selama proses belajar mengajar kebanyakan pendidik masih menggunakan metode teacher centered (Astriawati, 2017). Ini artinya proses pembelajaran masih berpusat pada pendidik dan peserta didik belum berperan aktif dalam belajar. Pembelajaran yang cenderung berpusat dan bersumber dari pendidik tidak mengajarkan peserta didik untuk mengonstruksi pelajaran dan mengakibatkan peserta didik bersifat pasif (Ahmad, Usodo, \& Riyadi, 2014)

Oleh sebab itu, diperlukan suatu cara pengajaran yang lebih terpusat kepada peserta didik agar peserta didik dapat mengonstruksi sendiri pelajaran yang diberikan oleh pendidik. Pendidik sebagai pendidik dan pengajar harus mampu menciptakan pembelajaran yang menarik di dalam kelas sehingga para peserta didik mampu berkonsentrasi dan menaruh minat pada proses pembelajaran. Gagne (dalam Pribadi, 2009), mendefinisikan istilah pembelajaran sebagai "a set of events embedded in purposeful activities that facilitate learning”. Pembelajaran adalah serangkaian aktivitas yang sengaja diciptakan dengan maksud untuk memudahkan terjadinya proses belajar.

Berkaitan dengan pengajaran yang mengkonstruksi pengetahuan peserta didik, Freudenthal (Wijaya, 2012) menyatakan sebaiknya peserta didik tidak mendapatkan konsep dari suatu pelajaran secara langsung, akan tetapi melalui kegiatan mengkonstruksi konsep matematika. Pengalaman peserta didik dalam kehidupan sehari-hari memiliki keterkaitan dengan konsep-konsep matematika. Terdapat beberapa pendekatan pembelajaran yang menggunakan konteks dunia nyata, salah satunya adalah pendekatan Realistic Mathematics Education (Prahmana, 2012). Pendekatan Realistic Mathematics Education dikembangkan oleh Institut Freudenthal sejak tahun 1971 yang didirikan oleh Prof. Hans Freudenthal (Hadi, 2017). Van den Heuvel Panhuizen (Wijaya, 2012) menyatakan bahwa Realistic Mathematics Education merupakan suatu pendekatan pembelajaran matematika yang tidak sekedar menunjukkan adanya suatu koneksi dengan dunia nyata, tetapi lebih mengacu pada fokus dalam menempatkan penekanan penggunaan suatu situasi yang bisa dibayangkan oleh peserta didik.

Sejumlah peneliti telah mendokumentasikan hasil penelitiannya terkait penggunakan pendekatan Realistic Mathematics Education menyatakan 
Pendekatan Pendidikan Matematika Realistik dapat meningkatan prestasi matematika peserta didik (Zakaria \& Syamaun, 2017). Selain itu hasil penelitian pendekatan Realistic Mathematics Education dapat memberikan pengaruh yang efektif dibandingkan dengan pembelajaran konvensional terhadap prestasi belajar, kemampuan penalaran matematis, dan minat belajar (Nurdiansyah, Charitas, \& Prahmana, 2017).

Berdasarkan uraian berbagai sumber tersebut, peneliti menggunakan pendekatan Realistic Mathematics Education sebagai pendekatan yang digunakan untuk menyampaikan pembelajaran kepada peserta didik dengan tujuan untuk meningkatkan minat belajar peserta didik.

\section{METODE}

Jenis penelitian yang digunakan dalam penelitian ini adalah True Eksperimen Design, yaitu dengan jenis Randomized Subject, Control-Group Pretest-Posttest Design. Desain dalam penelitian eksperimen ini, menggunakan kelompok kontrol. Antara kelompok eksperimen dan kelompok kontrol dilakukan secara acak dengan prinsip random assignment. Dalam desain ini peneliti melakukan pengukuran terlebih dahulu sebelum melakukan perlakuan (pre-test) dan setelah perlakuan (post-test). Penelitian eksperimen ini melibatkan satu kelas eksperimen yang diajar dengan menggunakan pendekatan Realistic Mathematics Education dan satu kelas kontrol yang diajar dengan tidak menggunakan pendekatan Realistic Mathematics Education.

Pada penelitian ini terdapat dua variabel yaitu variabel bebas (independent variabel) dan variabel terikat (dependent variabel).Variabel bebas yaitu pelaksanaan Realistic Mathematics Education dan variabel terikat yaitu minat belajar taruna. Populasi dalam penelitian ini adalah taruna jurusan Teknika Semester Gasal Tahun Akademik 2018/2019 yang mengambil mata kuliah Matematika Terapan. Populasi ditentukan sebanyak dua kelas yang terdiri dari 43 taruna yang dibagi menjadi dua kelas yaitu kelas eksperimen dan kelas kontrol. Sampel diambil secara random sebanyak 40 taruna masing-masing terdiri dari 20 taruna kelas A yang diambil untuk kelas eksperimen dan 20 taruna kelas B yang diambil untuk kelas kontrol.

Teknik pengumpulan data yang digunakan dalam penelitian ini adalah angket respon taruna terhadap minat belajar. Pengambilan angket dilaksanakan sebanyak dua kali, yaitu pre-test dan post-test. Pre-test dilaksanakan dengan tujuan untuk mengetahui minat belajar awal taruna pada kelas eksperimen dan kelas kontrol. Angket ini disebarkan sebelum kelas eksperimen dan kontrol menerima materi perkuliahan dan perlakuan pendekatan realistic mathematics education. Post-test pada kelas eksperimen dan kelas kontrol bertujuan untuk mengetahui peningkatan atau penurunan minat belajar taruna setelah diberikan perlakuan pendekatan Realistic Mathematics Education, dengan cara membandingkan dengan hasil pretest.

Instrumen penelitian yang digunakan adalah lembar observasi dan angket respon taruna. Pembuatan instrument angket respon taruna dalam penelitian ini menggunakan skala Likert dimana skala tersebut digunakan untuk menentukan tanggapan seseorang terhadap suatu fenomena mulai dari dangat negatif sampai 
dengan sangat positif. Pada penelitian ini yang digunakan adalah skala empat yang terdiri dari TS (Tidak Setuju), KS (Kurang Setuju), S (Setuju) dan SS (Sangat Setuju). Angket ini diberikan kepada semua taruna yang menjadi sampel penelitian baik kelas kontrol maupun kelas eksperimen. Angket terdiri dari 23 pertanyaan dalam 5 Indikator, yaitu (1) Indikator rasa tertarik, (2) indikator perasaan senang, (3) indikator perhatian, (4) indikator partisipasi dan (5) indikator keiginan/kesadaran. Indikator rasa tertarik sebanyak 6 pertanyaan, perasaan senang sebanyak 4 pertanyaan, perhatian sebanyak 4 pertanyaan, partisipasi sebanyak 5 pertanyaan dan keinginan/kesadaran sebanyak 4 pertanyaan.

Lembar observasi pelaksanaan pendekatan realistic mathematics education didasarkan pada tahap-tahap yang ada pada rencana pembelajaran semester (RPS) dan diobservasi oleh 1 orang yaitu peneliti. Kegiatan observasi merupakan kegiatan pengamatan pada hal- hal yang berhubungan dengan obyek/ subyek yang diteliti. Pada dasarnya observasi merupakan kegiatan pengamatan secara langsung (Sugiyono: 2013), sehingga teknik ini dapat mempermudah peneliti untuk mengamati proses pembelajaran secara langsung. Dalam penelitian ini, pokokpokok yang diamati adalah minat belajar taruna dalam proses belajar sebelum dan sesudah diberikan perlakuan pendekatan realistic mathematics education.

Sebelum digunakan dalam penelitian, instrumen lembar observasi dan angket respon taruna terlebih dahulu di validasi oleh ahli. Selain itu, instrumen soal telah dilakukan uji validitas dan uji realibilitas butir soal untuk mengetahui soal yang valid yang dapat digunakan untuk penelitian. Sampel penelitian berupa data kuantitatif. Data tersebut dianalisis dengan analisis deskriptif dan teknik analisis statistik inferensial.

Analisis deskriptif dilakukan untuk mendeskripsikan pelaksanaan pendekatan realistic mathematics education terhadap minat belajar taruna. Untuk melihat peningkatan minat belajar taruna sebelum dan sesudah diberikan treatment, peneliti menggunakan uji n-gain (Susanto, 2012). Berikut adalah rumus yang digunakan untuk mencari $n$-gain:

Keterangan:

$$
n-\text { gain }=\frac{\text { skor Post Test }- \text { skor pre test }}{\text { skor maksimal }- \text { skor pre test }}
$$

$n$-gain $(g) \quad$ : besarnya faktor gain

Skor posttest : nilai hasil tes akhir

Skor pretest : nilai hasil tes awal

Skor maksimal : nilai maksimal tes

Tabel 1. Kriteria Besarnya Faktor Gain

\begin{tabular}{l|l}
\hline Interval & Kriteria \\
\hline $\mathrm{g}>0,7$ & Tinggi \\
\hline $0,3 \leq \mathrm{g} \leq 0,7$ & Sedang \\
\hline $\mathrm{g}<0,3$ & Rendah \\
\hline
\end{tabular}




\section{HASIL DAN PEMBAHASAN}

Salah satu prinsip dari pendekatan Realistic Mathematic Education (RME) yaitu guided reinvention, didactical phenomenology dan self development models. Pada pertemuan pertama peneliti menggunakan prinsip guided reinventio dan didactical phenomenology. Berdasarkan prinsip guided reinvention dan didactical phenomenology dalam mengajukan masalah realistik peneliti hanya membimbing taruna untuk menemukan konsep dalam pembelajaran yang berhubungan dengan matematika dalam kontek realistik khususnya penerapan bidang teknika pelayaran.

Kegiatan yang dilakukan peneliti untuk mendapatkan tujuan tersebut adalah dengan membawa taruna ke Laboratorium Mesin Utama yang berisikan beberapa benda-benda yang dapat dihubungkan dengan konsep matematika. Benda-Benda tersebut diantaranya: mesin utama, mesin generator, pompa roda gigi, pompa ulir, pompa sentrifugal, Oil Water Separator, ketel uap, turbin uap, fresh water generator, mesin dua tak, Cooler. Peneliti meminta menyebutkan bentuk bangun datar maupun bangun ruang yang ada pada peralatan yang berada di laboratorium engine. Selanjutnya peneliti meminta taruna untuk mengukur benda baik panjang, lebar, jari-jari benda tersebut. Taruna pada kelas experiment dibagi menjadi 4 kelompok dengan tugas menyelidiki volume mapun luas permukaan yang ada di peralatan tersebut. Sedangkan untuk kelas kontrol hanya diberikan materi di dalam kelas.

Pada pertemuan selanjutnya, peneliti dalam proses perkuliahan di kelas experiment dilakukan model pembelajaran dengan pendekatan realistic mathematics education menggunakan prinsip self-development models. Menurut prinsip ini model-model di bangun berfungsi sebagai jembatan antara matematika formal dan pengetahuan informal. Dalam menyelesaikan masalah konstektual, taruna diberi kebebasan untuk membangun sendiri model matematika. Pada kelas experiment, peneliti mengajak taruna ke lapangan untuk menemukan permasalahan yang berhubungan dengan aktivitas taruna dengan kegiatan matematika. Selanjutnya mereka menemukan ide untuk melakukan baris berbaris dengan formasi lingkaran, kemudian melakukan permainan dengan menghitung luas lingkaran. Selain membentuk lingkaran, taruna juga membuat model barisan geometri datar yang mereka kuasai. Sedangkan untuk kelas kontrol hanya diberikan materi di dalam kelas.

Pengukuran minat belajar dilakukan dengan menggunakan uji $n$-gain agar dapat mengetahui seberapa besar penurunan atau peningkatan minat belajar taruna. Berikut adalah hasil pengukuran peningkatan minat belajar taruna:

Tabel 2. Hasil Pengukuran Minat Belajar Taruna Dengan Uji- Gain

\begin{tabular}{ccc}
\hline Klasifikasi & Kelas Kontrol & Kelas Eksperimen \\
\hline Rata- Rata Nilai Pretest & 61.2 & 57.7 \\
\hline Rata- Rata Nilai Posttest & 64.3 & 83.8 \\
\hline Nilai Maksimal & 92 & 92 \\
\hline$n$-Gain $(g)$ & 0.116 & 0.763 \\
\hline
\end{tabular}

Tabel di atas menunjukkan nilai rata-rata minat belajar taruna sebelum diberi perlakuan (pretest) untuk kelas kontrol sebesar 61.2 dan untuk kelas eksperimen 
sebesar 57.7. Sedangkan nilai rata-rata minat belajar taruna setelah diberi perkuliahan dengan pendekatan realistic mathematics education navigasi pelayaran untuk kelas kontrol sebesar 64.3, sedangkan untuk kelas eksperimen sebesar 83.8. Hasil uji n-gain untuk kelas kontrol diperoleh nilai n-gain sebesar $g=0.116$, menurut tabel 1 nilai $n$-gain $=0.116<0.3$ dalam kriteria rendah. Sedangkan untuk kelas eksperimen diperoleh nilai $n$-gain sebesar $g=0.763$, menurut tabel 1 nilai $n$ gain $=0.763>0.7$ dalam kriteria tinggi. Berdasarkan hasil uji $n$ - gain di atas peningkatan minat belajar taruna mendapat nilai gain sebesar 0.73 , jika dimasukkan ke dalam kriteria faktor gain maka nilai tersebut tergolong dalam kriteria tinggi. Hal ini menunjukkan bahwa peningkatan minat belajar taruna setelah perlakuan dengan pendekatan realistic mathematics education dalam kriteria tinggi. Perbedaan hasil uji $n$-gain tersebut menunjukkan pendekatan realistic mathematics education berpengaruh untuk meningkatkan minat belajar taruna.

Angket minat belajar dikriteriakan menjadi beberapa indikator yaitu rasa tertarik, perasaan senang, perhatian, partisipasi dan keingian/ kesadaran. Jika hasil pengukuran minat belajar dijabarkan per- indikator, maka dapat diperoleh hasil seperti yang terlihat pada tabel berikut;

Tabel 3. Hasil pengukuran minat belajar per- indikator dengan uji n-gain

\begin{tabular}{cccccccccc}
\hline Indikator & $\begin{array}{c}\text { nilai } \\
\text { max }\end{array}$ & \multicolumn{4}{c}{ Kelas Kontrol } & \multicolumn{4}{c}{ Kelas Eksperimen } \\
\cline { 3 - 9 } & & Pretest & Posttest & $\begin{array}{c}\boldsymbol{n} \text { - } \\
\text { gain(g) }\end{array}$ & $\begin{array}{c}\text { besar } \\
\text { kenaikan }\end{array}$ & Pretest & Posttest & $\begin{array}{c}\boldsymbol{n} \text { - } \\
\text { gain(g) }\end{array}$ & $\begin{array}{c}\text { besar } \\
\text { kenaikan }\end{array}$ \\
\hline $\begin{array}{c}\text { Rasa } \\
\text { tertarik }\end{array}$ & 24 & 15.5 & 16.6 & 0.176 & 1,1 & 14.3 & 21.25 & 0.713 & 6,95 \\
\hline $\begin{array}{c}\text { Perasaan } \\
\text { senang }\end{array}$ & 16 & 11.6 & 12.05 & 0.063 & 0,45 & 11.5 & 14.3 & 0.605 & 2,8 \\
\hline Perhatian & 16 & 10.9 & 11.65 & 0.154 & 0,75 & 11.1 & 14.6 & 0.709 & 3,5 \\
\hline Partisipasi & 20 & 14.15 & 14.25 & 0.010 & 0,1 & 9.85 & 18.75 & 0.623 & 8,9 \\
\hline Keinginan & 16 & 9.45 & 10.35 & 0.109 & 0,9 & 10.95 & 14.85 & 0.786 & 3,9 \\
\hline
\end{tabular}

Berdasarkan Tabel 3, dapat diketahui bahwa semua indikator kelas kontrol dalam kriteria rendah, hal ini terbukti dengan nilai $n$-gain $=\mathrm{g}<0.3$. Sedangkan untuk kelas eksperimen ada 3 indikator dalam kriteria tinggi, hal ini dibuktikan dengan nilai $n$-gain $=$ $\mathrm{g}>0.7$, yaitu indikator rasa tertarik, indikator perhatian dan indikator keinginan. Sedangkan untuk indikator perasaan senang dan partisipasi hanya memperoleh kriteria sedang, hal ini dibuktikan dengan nilai $n$-gain $=\mathrm{g}>0.7$. Hal ini terbukti dengan nilai $n$ gain diantara $0,3 \leq \mathrm{g} \leq 0,7$. Pada kelas kontrol, rasa tertarik memiliki $n$-gain paling tinggi yaitu 0.176 , akan tetapi masih dalam kriteria rendah karena $n$-gain $=0.176<$ 0.3. Sedangkan untuk kelas eksperimen, indikator keinginan memiliki n-gain paling tinggi yaitu 0.786 . Menurut tabel 1 nilai $n$-gain $=0.786>0.7$ nilai tersebut tergolong dalam kriteria tinggi. Hal ini menunjukkan bahwa peningkatan minat belajar taruna setelah perlakuan dengan pendekatan realistic mathematics education khususnya indikator keinginan untuk mengikuti perkuliahan sangat tinggi. Perbedaan hasil uji n-gain diatas menunjukkan pendekatan Realistic Mathematics Education navigasi pelayaran berpengaruh terhadap meningkatnya minat belajar taruna.

Nilai rata-rata indikator kelas kontrol maupun kelas ekperimen diperoleh (1) Untuk indikator rasa tertarik untuk kelas kontrol mendapat kenaikan sebesar 1.1, sedangkan untuk kelas eksperimen mendapat nilai 6.95, (2) Indikator perasaan 
senang untuk kelas kontrol mendapat kenaikan sebesar 0.45 , sedangkan untuk kelas eksperimen mendapat nilai 2.8, (3) Indikator perhatian untuk kelas kontrol mendapat kenaikan sebesar 0.75 , sedangkan untuk kelas eksperimen mendapat nilai 3.5, (4) Indikator partisipasi untuk kelas kontrol mendapat kenaikan sebesar 0.45, sedangkan untuk kelas eksperimen mendapat nilai 2.8, (5) Indikator keinginan untuk kelas kontrol mendapat kenaikan sebesar 0.9, sedangkan untuk kelas eksperimen mendapat nilai 3.9. Dengan demikian dapat dinyatakan bahwa rata-rata kenaikan kelas eksperimen lebih tinggi dibandingkan dengan kelas kontrol, terlihat dari semua indikator yang ada, sehingga hal ini menunjukkan bahwa peningkatan minat belajar taruna setelah perlakuan dengan pendekatan Realistic Mathematics Education navigasi pelayaran berpengaruh terhadap minat belajar taruna secara keseluruhan.

Selain menggunakan angket respon taruna, peneliti juga melakukan observasi selama perkuliahan berlangsung. Berdasarkan pengamatan yang dilakukan oleh peneliti pada saat perkuliahan, taruna pada kelas eksperimen lebih berminat mengikuti perkuliahan, hal ini dibuktikan dengan aktifitas taruna, sebagian besar taruna lebih aktif untuk mengajukan pertanyaan ketika dirasa mereka tidak mengerti dengan apa yang disampaikan dan ketika dosen bertanya mereka cepat memberikan feedback utnuk menyelesaikan persoalan yang diberikan. Selain itu, perkuliahan menjadi lebih bermakna dan menyenangkan bagi taruna, ditunjukkan dengan banyak taruna yang merasa senang dan mampu mengingat konsep matematika yang telah diberikan.

Aktivitas taruna tersebut merupakan aktivitas belajar, sesuai dengan teori yang dikemukakan Gagne (dalam Pribadi, 2009) dimana belajar merupakan sebuah proses pengembangan, keterampilan, pengetahuan dan sikap yang terjadi saat seseorang melakukan interaksi secara intensif.

\section{SIMPULAN}

Pelaksanaan pendekatan Realistic Mathematics Education sangat berpengaruh untuk meningkatkan minat belajar taruna, hal ini ditunjukkan terdapat perbedaan yang signifikan nilai $n$-gain yang diperoleh dari kelas kontrol sebesar $n$ gain $=0.116$ dalam kreteria rendah, sedangkan kelas eksperimen memperoleh nilai sebesar $n$-gain $=0.763$ dalam kriteria tinggi. Disamping itu memperlihatkan taruna memiliki respon yang sangat positif terhadap pembelajaran Matematika Terapan dengan menggunakan pendekatan realistic mathematics education.

Berdasarkan kesimpulan tersebut, maka disarankan dosen matematika dapat menggunakan pendekatan realistic mathematics education sebagai alternatif pendekatan pembelajaran untuk meningkatkan minat belajar taruna.

\section{DAFTAR PUSTAKA}

Ahmad, A., Usodo, B., \& Riyadi, R. (2014). Eksperimentasi model pembelajaran kooperatif tipe group investigation (GI) dan jigsaw II pada materi pokok bangun ruang ditinjau dari kemampuan spasial peserta didik kelas VIII SMP Negeri sekabupaten Karanganyar tahun pelajaran 2013/2014. Jurnal Elektronik 
Pembelajaran Matematika, 2(8), 804-815. Retrieved from http://jurnal.fkip.uns.ac.id/index.php/s2m ath/article/view/4821

Astriawati, N. (2017). Diagnosis model pembelajaran Blended Learning dengan teknik scaffolding. Bahari Jogja, XV, 1-12. Retrieved from http://jurnal.amy.ac.id/index.php/MIBJ/article/view/95/93

Hadi, S. (2017). Pendidikan matematika realistik: Teori, pengembangan dan implementasinya. Jakarta: Rajawali Pers.

Nurdiansyah, N., Charitas, R., \& Prahmana, I. (2017). Abstrak Learning Circumference Using the Context of Glass, 4(2), 128-140.

Prahmana, R. C. I. (2012, January 17). Pendesainan pembelajaran operasi bilangan menggunakan permainan tradisional tepuk bergambar untuk peserta didik kelas III sekolah dasar (SD). Univesitas Sriwijaya. https://doi.org/10.13140/RG.2.2.33884.59529

Prahmana, R. C. I., Zulkardi, Z., \& Hartono, Y. (2012). Learning multiplication using indonesian traditional game in third grade. Journal on Mathematics Education, 3(2). Retrieved from http://ejournal.unsri.ac.id/index.php/jme/a rticle/view/570

Pribadi, A., Benny. (2009). Model Desain Pembelajaran. Jakarta: Dian Rakyat

Slameto. (1995). Belajar dan faktor-faktor yang mempengaruhinya. Jakarta: Rineka Cipta. Edisi revisi .

Sugiyono. (2013). Metodologi Penelitian Kuantitatif, Kualitatif, R \& D. Bandung: Alfabeta.

Wijaya, A. (2012). Pendidikan matematika realistik: Suatu alternatif pendekatan pembelajaran matematika. Yogyakarta: Graha Ilmu.

Zakaria, E., \& Syamaun, M. (2017). The Effect of Realistic Mathematics Education Approach on Students' Achievement And Attitudes Towards Mathematics. Mathematics Education Trends and Research, 2017(1), 32-40. https://doi.org/10.5899/2017/metr-00093 